\title{
Description of suicide ideation among older adults and a psychological profile: a cross-sectional study in Turkey
}

\author{
Descrição da ideação suicida em idosos e perfil psicológico: \\ um estudo transversal na Turquia
}

Murat Aslan (https://orcid.org/0000-0002-9507-4330) ${ }^{1}$

Cicek Hocaoglu (https://orcid.org/0000-0001-6613-4317) ${ }^{1}$

Bulent Bahceci (https://orcid.org/0000-0002-7591-3643) ${ }^{1}$

${ }^{1}$ Department of Psychiatry, Medical School, Recep Tayyip Erdogan University. Fener Mh 53000.

Merkez Rize Turkey. murataslan_48@

hotmail.com

\begin{abstract}
This study investigates the suicidal ideation and the possible causes for suicidal behaviour in the elderly. Subjects were 150 patients aged 65 and older who were evaluated using the sociodemographic data collection forms, Geriatric Depression Scale (GDS), Suicidal Ideation Scale (SIS), Reasons for Living Inventory (RLI), and Beck Hopelessness Scale (BHS). Of 150 patients, $72.7 \%$ were women and $27.3 \%$ were men, ages ranged from 65 to 88 years. Suicidal ideation was noted in $30.7 \%$ of patients. When the mean of BHS total score between patients with and without suicidal ideation and the mean of BHS subscale's feelings and expectations regarding the future and loss of motivation and hope in terms of subscales were evaluated between the groups with and without suicidal ideation, the scores had a significant difference. When RLI was evaluated in terms of total scores, the suicidal ideation mean score was $243.74 \pm 32.28$, while the non-suicidal ideation mean score was $267.27 \pm 24.36$. There was a significant relationship between the two groups. We found low level of education, low level of reasons for living and higher psychiatric morbidity (generalized anxiety disorder and comorbid depressive disorder) in with suicidal ideation in the elderly.
\end{abstract}

Key words Elderly, Hopelessness, Suicidal ideation, Reasons for living
Resumo Este estudo tem por objetivo investigar os fatores que levam à ideação suicida e às possíveis causas para o comportamento suicida em idosos. Foram estudados 150 pacientes com idade igual ou superior a 65 anos, que foram avaliados utilizando os formulários de coleta de dados sociodemográficos, Escala de Depressão Geriátrica (EDG), Escala de Ideação Suicida (EIS), Inventário de Razões para Viver (IRV) e Escala de Desesperança de Beck (EDB). De 150 pacientes, 72,7\% eram mulheres e $27,3 \%$ homens, com idades de 65 a 88 anos. A ideação suicida foi observada em $30,7 \%$ dos pacientes. Ao se avaliar a média da pontuação total de EBD entre pacientes com e sem ideação suicida e a média dos sentimentos e expectativas da subescala EBD em relação ao futuro e perda de motivação e esperança em termos de subescalas entre os grupos com e sem ideação suicida, a pontuação teve uma diferença significativa. Quando o IRV foi avaliado em termos de pontuações totais, o escore médio de ideação suicida foi de $243,74 \pm 32,28$, enquanto o escore médio de ideação não suicida foi de 267,27 $\pm 24,36$. Houve uma relação significativa entre os dois grupos. Fatores de risco para ideação suicida em idosos foram desesperança, baixo nível de educação, baixo nivel de razões para viver, distúrbio de ansiedade generalizada e transtorno depressivo comórbido.

Palavras-chave Idosos, Desesperança, Ideação suicida, Razões para viver 


\section{Introduction}

Old age is a stage in the human life cycle in which the suicide rate increases. The completed suicide rate of elderly men is 3-4 times higher than the overall average worldwide ${ }^{1}$. Suicidal ideation is quite common when compared with suicidal behaviour, and lifetime prevalence of suicidal ideation in the community varies from approximately $13.5 \%$ to $35 \%^{2}$. Temporary suicidal ideation usually does not lead to an impulsive suicide attempt and risk of death, but insistent, repetitive and intense death and suicide ideation is a high and immediate risk. The risk increases when detailed suicidal ideas with clear and concrete plans continue for an extended period, and the suicidal individual has made his/her intentions clear to people around him/her. Moreover, making preparations, such as creating a will, leaving a suicide note and saying goodbye to relatives, for committing suicide are significantly higher risk indicators $^{3}$. Suicides are approximately five times more common in populations aged $>65$ years than the general population in the United States; $25 \%$ of suicides are realized among the elderly, although they comprise only approximately $10 \%$ of the general population ${ }^{4}$. Risk factors for suicide among the elderly include being a man, losing spouses and relatives, living alone, having weak religious and family bonds, being in the minority, experiencing economic and social status deprivation that accompanies ageing and enduring physical and mental illnesses 5 . Depressive symptoms are one of the most important causes of suicide in the elderly. An ongoing sense of despair unrelated to depressive symptoms and lack of purpose to continue living are independent factors that increase suicide risk. Some studies have noted a mutual interaction between the emergence of mental disorders and biological, psychological and social conditions in the lives of the elderly ${ }^{3}$.

This study aimed to investigate the factors (socio-demographic and clinical characteristics) that lead to suicidal ideation and the possible causes for suicidal behaviour in the elderly, thereby contributing to research in the area of hopelessness and suicidal ideation in the elderly.

\section{Methods}

\section{Participants}

In this study, participants were patients ( $\mathrm{n}=$ 150 ; age, $\geq 65$ years) with psychiatric symptoms who were sequentially admitted to the Rize Education and Research Hospital Clinic of Psychiatry from 3 January 2012 to 3 January 2013. Patients with neurological diseases, mental retardation, dementia, psychotic disorder (because of a general medical condition or use of alcohol or drugs) and moderate-to-severe cognitive impairment [i.e. a Standardized Mini-Mental Test (SMMT) score of $<24$ points] were excluded. Moreover, patients with a history of recent (within 6 last months) or current use of antidepressant drugs were excluded. The study was performed with the approval of the Faculty of Medicine Clinical Research Ethics Committee in Recep Tayyip Erdogan University (date of approval: 20.04.2012; number: 2012/61) and was conducted in accordance with the Declaration of Helsinki. Patients agreed to participate in the study by signing an informed consent form after receiving information regarding the study objectives. The Structured Clinical Interview for DSM-IV Axis I Disorders was applied to confirm Axis I diagnoses and to determine comorbidity diagnose.

\section{Measurements}

\section{The Sociodemographic Data Collection Form}

The sociodemographic data collection form comprises questions regarding age, gender, marital status, place of residence, economic status, history of psychiatric disorders, history of previous suicide attempts and methods, history of suicide and psychiatric disorders in the patient's family.

\section{The Geriatric Depression Scale}

Geriatric Depression Scale (GDS) is a 30-item self-report questionnaire that is used to identify depression in the geriatric population. The questionnaire was first developed in 1982 by Yesavage et al. Patients marked each item as 'Yes' or 'No'. The cut-off point of the scale was considered to be $13 / 14$. The Turkish validity and reliability of the scale was performed by Ertan et al. ${ }^{6}$.

\section{The Suicidal Ideation Scale}

Suicidal Ideation Scale (SIS) was developed to evaluate the intensity of suicidal ideation in an individual, individual's attitudes towards these thoughts, degree of intention to realize this suicidal ideation and factors determining the intention and determination to implement these plans. Each item in the scale is marked as 'True \& False' or 'Yes \& No', and scoring is made between 
0 and 1 points. The high scores demonstrate the intensity of suicidal ideation and the high risk of realization. The Turkish translation of the scale was made by Dilbaz et al. .

\section{The Beck Hopelessness Scale}

Beck Hopelessness Scale (BHS), which measures the negative expectations of an individual for the future, comprises 20 items that are scored between 0 and 1 points. Individuals mark compliant expressions as 'Yes' and noncompliant ones as 'No'. The Turkish validity and reliability of the scale was performed by Durak and Palabiyikoglu ${ }^{8}$.

\section{The Reasons for Living Inventory}

Reasons for Living Inventory (RLI) was developed by Linehan et al. to determine positive and negative reasons that prevent suicidal behaviour in individuals. The original form of RLI contains 48 items. This study used the 70-item form that was adapted to the Turkish culture by Durak et al. ${ }^{9}$. Score ranges from 70 to 420 and it is scored in Likert type between 1 and 6. The scale consists of 6 short subscales: general optimism, moral and religious obstacles, responsibility and love for the family and friends, fear of suicide and its negative consequences, devotion to nature and life, and fear of death.

\section{Statistical Analyses}

We used the statistical software program Statistical Analysis System (SAS, 2002, Ver. 9.0, Cary, NC, USA) for statistical analyses. Patients were subjected to frequency analysis (Proc Freq procedure) after they were grouped according to demographics, psychiatric history and suicidal ideation. The difference between SMMT, SIS, GDS, BHS and RLI total and subscales of individuals with and without suicidal ideation was determined using the Student's t-test. $P$ values of $<0.05$ were considered statistically significant.

\section{Results}

Subjects were 150 elderly patients who were admitted to an outpatient psychiatric clinic. Of 150 patients, $72.7 \%$ were women $(n=109)$ and $27.3 \%$ were men $(n=41)$, ages ranged from 65 to 88 years and mean age was $71.3 \pm 5.6$. Suicidal ideation was noted in $30.7 \%$ of patients $(n=46)$, whereas no suicidal ideation was noted in $69.3 \%$ of patients $(n=104)$. As shown in Table 1 , no sta- tistically significant difference was noted between groups with and without suicidal ideation when sociodemographic characteristics were examined $(p>0.05)$. It was determined that there is a significant difference between two groups only in terms of education level. Accordingly, the group with suicidal ideation has a lower education level $(p<0.001)$. Of nine patients who attempted suicide, seven had suicidal ideation and two had no suicidal ideation. There was a significant difference between the groups with and without suicidal ideation $(p=0.0016)$.

The distribution of psychiatric disorders among patients according to the presence of suicidal ideation is given in Table 2. According to this, there is no statistically significant difference between groups with or without suicidal ideation in terms of distribution of psychiatric diseases (except generalized anxiety disorder and comorbid depressive disorder $(\mathrm{p}=0.032)$. Only generalized anxiety disorder and comorbid depressive disorder levels were found to be significantly high in the group with suicidal ideation $(\mathrm{p}=0.032)$.

Mean patient scores for GDS, BHS and RLI are listed according to the presence of suicidal ideation in Table 3. Mean GDS scores were 18.98 \pm 3.84 and $14.69 \pm 4.86$ in the groups with and without suicidal ideation, respectively (Table 3 ). Accordingly, the mean of the group with suicidal ideation was higher, and there were significant differences between the groups $(P=0.0001)$. Total mean BHS scores were $12.22 \pm 4.66$ and 8.63 \pm 5.69 in the groups with and without suicidal ideation, respectively (Table 3 ). According to these values, we found a significant difference between the two groups $(p=0.0002)$.We also noted statistical significance in terms of BHS subscales (i.e. feelings and expectations for the future and loss of motivation and hope) between the groups with and without suicidal ideation $(p<0.05)$. RLI is worth noting that the mean scores received from all subscales of patients with suicidal ideation were higher than those of patients without suicidal ideation. Total mean RLI scores were $243.74 \pm 32.28$ and $267.27 \pm 24.36$ in the groups with and without suicidal ideation, respectively (Table 3). It was found that the mean score of patients in the group without suicidal ideation was higher than that in the group with suicidal ideation; there was a significant relationship between the two groups $(\mathrm{p}<0.05)$. Statistically significant results between both groups are shown in Graph 1.

Of nine patients in the study ( $n=8$ women; $\mathrm{N}=1$ man) who had attempted suicide in the 
Table 1. Comparison of socio-demographic and clinical characteristics of patients with and without suicidal ideation.

\begin{tabular}{|c|c|c|c|c|c|}
\hline & & & $\begin{array}{c}\text { With Suicidal } \\
\text { Ideation }\end{array}$ & $\begin{array}{c}\text { Without Suicidal } \\
\text { Ideation }\end{array}$ & $\mathbf{P}$ \\
\hline \multirow[t]{6}{*}{ Gender } & Female & Count & 37 & 72 & 0.156 \\
\hline & & Row N \% & $33.9 \%$ & $66.1 \%$ & \\
\hline & & Column N \% & $80.4 \%$ & $69.2 \%$ & \\
\hline & Male & Count & 9 & 32 & \\
\hline & & Row N \% & $22.0 \%$ & $78.0 \%$ & \\
\hline & & Column N \% & $19.6 \%$ & $30.8 \%$ & \\
\hline \multirow[t]{9}{*}{ Age Range } & $65-74$ & Count & 34 & 77 & 0.316 \\
\hline & & Row N \% & $30.6 \%$ & $69.4 \%$ & \\
\hline & & Column N \% & $73.9 \%$ & $74.0 \%$ & \\
\hline & $75-84$ & Count & 9 & 25 & \\
\hline & & Row N \% & $26.5 \%$ & $73.5 \%$ & \\
\hline & & Column N \% & $19.6 \%$ & $24.0 \%$ & \\
\hline & 85 and over & Count & 3 & 2 & \\
\hline & & Row N \% & $60.0 \%$ & $40.0 \%$ & \\
\hline & & Column N \% & $6.5 \%$ & $1.9 \%$ & \\
\hline \multirow[t]{12}{*}{ Educational Status } & Illiterate & Count & 28 & 28 & $<0.001$ \\
\hline & & Row N \% & $50.0 \%$ & $50.0 \%$ & \\
\hline & & Column N \% & $60.9 \%$ & $26.9 \%$ & \\
\hline & Literate & Count & 11 & 28 & \\
\hline & & Row N \% & $28.2 \%$ & $71.8 \%$ & \\
\hline & & Column N \% & $23.9 \%$ & $26.9 \%$ & \\
\hline & Primary school & Count & 6 & 38 & \\
\hline & & Row N \% & $13.6 \%$ & $86.4 \%$ & \\
\hline & & Column N \% & $13.0 \%$ & $36.5 \%$ & \\
\hline & Middle school & Count & 1 & 10 & \\
\hline & & Row N \% & $9.1 \%$ & $90.9 \%$ & \\
\hline & & Column N \% & $2.2 \%$ & $9.6 \%$ & \\
\hline \multirow[t]{6}{*}{ Marital Status } & Married & Count & 25 & 61 & 0.623 \\
\hline & & Row N \% & $29.1 \%$ & $70.9 \%$ & \\
\hline & & Column N \% & $54.3 \%$ & $58.7 \%$ & \\
\hline & Widowed & Count & 21 & 43 & \\
\hline & & Row N \% & $32.8 \%$ & $67.2 \%$ & \\
\hline & & Column N \% & $45.7 \%$ & $41.3 \%$ & \\
\hline \multirow[t]{9}{*}{ Occupation } & Housewife & Count & 37 & 69 & 0.217 \\
\hline & & Row N \% & $34.9 \%$ & $65.1 \%$ & \\
\hline & & Column N \% & $80.4 \%$ & $66.3 \%$ & \\
\hline & Retired & Count & 8 & 31 & \\
\hline & & Row N \% & $20.5 \%$ & $79.5 \%$ & \\
\hline & & Column N \% & $17.4 \%$ & $29.8 \%$ & \\
\hline & Artisan & Count & 1 & 4 & \\
\hline & & Row N \% & $20.0 \%$ & $80.0 \%$ & \\
\hline & & Column N \% & $2.2 \%$ & $3.8 \%$ & \\
\hline
\end{tabular}

past, $44.4 \%(n=4)$ attempted suicide $>20$ years ago. The most common suicide method used by $33.3 \%$ of these nine patients was using drug $(n=$
3). The most common suicide method used by $44.4 \%$ of these nine patients with a history of suicide in their families was hanging $(n=4)$. 
Table 1. Comparison of socio-demographic and clinical characteristics of patients with and without suicidal ideation.

\begin{tabular}{|c|c|c|c|c|c|}
\hline & & & $\begin{array}{c}\text { With Suicidal } \\
\text { Ideation }\end{array}$ & $\begin{array}{c}\text { Without Suicidal } \\
\text { Ideation }\end{array}$ & $\mathbf{P}$ \\
\hline \multirow[t]{9}{*}{ Place of residence } & \multirow[t]{3}{*}{ Province } & Count & 9 & 36 & 0.169 \\
\hline & & Row N \% & $20.0 \%$ & $80.0 \%$ & \\
\hline & & Column N \% & $19.6 \%$ & $34.6 \%$ & \\
\hline & \multirow[t]{3}{*}{ County } & Count & 17 & 29 & \\
\hline & & Row N \% & $37.0 \%$ & $63.0 \%$ & \\
\hline & & Column N \% & $37.0 \%$ & $27.9 \%$ & \\
\hline & \multirow[t]{3}{*}{ Village } & Count & 20 & 39 & \\
\hline & & Row N \% & $33.9 \%$ & $66.1 \%$ & \\
\hline & & Column N \% & $43.5 \%$ & $37.5 \%$ & \\
\hline \multirow[t]{9}{*}{ Income (TL) } & \multirow[t]{3}{*}{ 0-599 TL } & Count & 13 & 15 & 0.128 \\
\hline & & Row N \% & $46.4 \%$ & $53.6 \%$ & \\
\hline & & Column N \% & $28.3 \%$ & $14.4 \%$ & \\
\hline & \multirow[t]{3}{*}{ 600-1499 TL } & Count & 25 & 65 & \\
\hline & & Row N \% & $27.8 \%$ & $72.2 \%$ & \\
\hline & & Column N \% & $54.3 \%$ & $62.5 \%$ & \\
\hline & \multirow{3}{*}{$\begin{array}{l}1500 \text { and over } \\
\text { TL }\end{array}$} & Count & 8 & 24 & \\
\hline & & Row N \% & $25.0 \%$ & $75.0 \%$ & \\
\hline & & Column N \% & $17.4 \%$ & $23.1 \%$ & \\
\hline \multirow{12}{*}{$\begin{array}{l}\text { Experienced by } \\
\text { Family members }\end{array}$} & \multirow[t]{3}{*}{ Wife } & Count & 20 & 32 & 0.107 \\
\hline & & Row N \% & $38.5 \%$ & $61.5 \%$ & \\
\hline & & Column N \% & $43.5 \%$ & $30.8 \%$ & \\
\hline & \multirow[t]{3}{*}{ Single child } & Count & 7 & 8 & \\
\hline & & Row N \% & $46.7 \%$ & $53.3 \%$ & \\
\hline & & Column N \% & $15.2 \%$ & $7.7 \%$ & \\
\hline & \multirow[t]{3}{*}{ Others } & Count & 15 & 45 & \\
\hline & & Row N \% & $25.0 \%$ & $75.0 \%$ & \\
\hline & & Column N \% & $32.6 \%$ & $43.3 \%$ & \\
\hline & \multirow[t]{3}{*}{ Alone } & Count & 4 & 19 & \\
\hline & & Row N \% & $17.4 \%$ & $82.6 \%$ & \\
\hline & & Column N \% & $8.7 \%$ & $18.3 \%$ & \\
\hline
\end{tabular}

\section{Discussion}

A total of 150 elderly patients who were admitted to an outpatient psychiatric clinic in this study were divided into two groups including those with and without suicidal ideation and were evaluated in terms of sociodemographic and clinical characteristics. We observed that of our 150 patients, $30.7 \%$ had suicidal ideation and $69.3 \%$ had no suicidal ideation. In another study, authors determined the suicidal ideation rate to be $(38 \%)^{10}$. Although we found no statistically significant difference between women and men with suicidal ideation, the proportion of women was higher. This finding is in compliance with a 
Table 1. Comparison of socio-demographic and clinical characteristics of patients with and without suicidal ideation .

\begin{tabular}{|c|c|c|c|c|c|}
\hline & & & $\begin{array}{c}\text { With Suicidal } \\
\text { Ideation }\end{array}$ & $\begin{array}{c}\text { Without Suicidal } \\
\text { Ideation }\end{array}$ & $\mathbf{P}$ \\
\hline \multirow{24}{*}{$\begin{array}{l}\text { History of Chronic } \\
\text { illness }\end{array}$} & \multirow[t]{3}{*}{ Absent } & Count & 8 & 8 & 0.216 \\
\hline & & Row N \% & $50.0 \%$ & $50.0 \%$ & \\
\hline & & Column N \% & $17.4 \%$ & $7.7 \%$ & \\
\hline & \multirow{3}{*}{$\begin{array}{l}\text { Diabetes } \\
\text { mellitus }\end{array}$} & Count & 1 & 10 & \\
\hline & & Row N \% & $9.1 \%$ & $90.9 \%$ & \\
\hline & & Column N \% & $2.2 \%$ & $9.6 \%$ & \\
\hline & \multirow[t]{3}{*}{ Cardiovascular } & Count & 24 & 51 & \\
\hline & & Row N \% & $32.0 \%$ & $68.0 \%$ & \\
\hline & & Column N \% & $52.2 \%$ & $49.0 \%$ & \\
\hline & \multirow[t]{3}{*}{ Respiratory } & Count & 2 & 4 & \\
\hline & & Row N \% & $33.3 \%$ & $66.7 \%$ & \\
\hline & & Column N \% & $4.3 \%$ & $3.8 \%$ & \\
\hline & \multirow{3}{*}{$\begin{array}{l}\text { Diabetes } \\
\text { melitüs+ } \\
\text { Cardiovasküler }\end{array}$} & Count & 9 & 16 & \\
\hline & & Row N \% & $36.0 \%$ & $64.0 \%$ & \\
\hline & & Column N \% & $19.6 \%$ & $15.4 \%$ & \\
\hline & \multirow[t]{3}{*}{ Cancer } & Count & 1 & 7 & \\
\hline & & Row N \% & $12.5 \%$ & $87.5 \%$ & \\
\hline & & Column N \% & $2.2 \%$ & $6.7 \%$ & \\
\hline & \multirow[t]{3}{*}{ Musculoskeletal } & Count & 1 & 2 & \\
\hline & & Row N \% & $33.3 \%$ & $66.7 \%$ & \\
\hline & & Column N \% & $2.2 \%$ & $1.9 \%$ & \\
\hline & \multirow[t]{3}{*}{ Others } & Count & 0 & 6 & \\
\hline & & Row N \% & $.0 \%$ & $100.0 \%$ & \\
\hline & & Column N \% & $.0 \%$ & $5.8 \%$ & \\
\hline \multirow{6}{*}{$\begin{array}{l}\text { History of } \\
\text { psychiatric illness }\end{array}$} & \multirow[t]{3}{*}{ Available } & Count & 19 & 31 & 0.168 \\
\hline & & Row N \% & $38.0 \%$ & $62.0 \%$ & \\
\hline & & Column N \% & $41.3 \%$ & $29.8 \%$ & \\
\hline & \multirow[t]{3}{*}{ Absent } & Count & 27 & 73 & \\
\hline & & Row N \% & $27.0 \%$ & $73.0 \%$ & \\
\hline & & Column N \% & $58.7 \%$ & $70.2 \%$ & \\
\hline \multirow{6}{*}{$\begin{array}{l}\text { Family history of } \\
\text { psychiatric illness }\end{array}$} & \multirow[t]{3}{*}{ Available } & Count & 9 & 31 & 0.191 \\
\hline & & Row N \% & $22.5 \%$ & $77.5 \%$ & \\
\hline & & Column N \% & $19.6 \%$ & $29.8 \%$ & \\
\hline & \multirow[t]{3}{*}{ Absent } & Count & 37 & 73 & \\
\hline & & Row N \% & $33.6 \%$ & $66.4 \%$ & \\
\hline & & Column N \% & $80.4 \%$ & $70.2 \%$ & \\
\hline \multirow[t]{6}{*}{ Suicide Attempt } & \multirow[t]{3}{*}{ Available } & Count & 7 & 2 & 0.002 \\
\hline & & Row N \% & $77.8 \%$ & $22.2 \%$ & \\
\hline & & Column N \% & $15.2 \%$ & $1.9 \%$ & \\
\hline & \multirow[t]{3}{*}{ Absent } & Count & 39 & 102 & \\
\hline & & Row N \% & $27.7 \%$ & $72.3 \%$ & \\
\hline & & Column N \% & $84.8 \%$ & $98.1 \%$ & \\
\hline \multirow{6}{*}{$\begin{array}{l}\text { Completed suicide } \\
\text { in the family }\end{array}$} & \multirow[t]{3}{*}{ Available } & Count & 5 & 4 & 0.095 \\
\hline & & Row N \% & $55.6 \%$ & $44.4 \%$ & \\
\hline & & Column N \% & $10.9 \%$ & $3.8 \%$ & \\
\hline & \multirow[t]{3}{*}{ Absent } & Count & 41 & 100 & \\
\hline & & Row N \% & $29.1 \%$ & $70.9 \%$ & \\
\hline & & Column N \% & $89.1 \%$ & $96.2 \%$ & \\
\hline
\end{tabular}

Turkish Lira: TL 
Table 2. Distribution of psychiatric disorders among patients according to the presence of suicidal ideation.

\begin{tabular}{|c|c|c|c|c|c|}
\hline & \multicolumn{2}{|c|}{$\begin{array}{c}\text { With Suicidal } \\
\text { Ideation (n \%) }\end{array}$} & \multicolumn{2}{|c|}{$\begin{array}{l}\text { Without Suicidal } \\
\text { Ideation(n \%) }\end{array}$} & \multirow[b]{2}{*}{ p-value } \\
\hline & $\mathbf{n}$ & $\%$ & $\mathbf{n}$ & $\%$ & \\
\hline Depressive disorder & 11 & 23.9 & 23 & 22.9 & 0.808 \\
\hline Generalized anxiety disorder & 2 & 4.3 & 14 & 13.5 & 0.095 \\
\hline Normal psychiatric examination & 0 & 0.0 & 6 & 5.8 & 0.096 \\
\hline Dysthymia & 1 & 2.2 & 9 & 8.7 & 0.130 \\
\hline Dysthymia+Anxiety disorder & 5 & 10.9 & 10 & 9.6 & 0.813 \\
\hline Generalized anxiety disorder + Depressive disorder & 24 & 52.2 & 35 & 33.7 & 0.032 \\
\hline Somatization disorder & 3 & 6.5 & 3 & 2.9 & 0.295 \\
\hline Primary insomnia & 3 & 6.5 & 4 & 3.8 & 0.474 \\
\hline
\end{tabular}

Table 3. Mean (sd)scores from the Geriatric Depression Scale (GDS), the Beck Hopelessness Scale (BHS), and the Reasons for Living Inventory (RLI) of patients with and without suicidal ideation.

\begin{tabular}{lcrr}
\hline & With Suicidal Ideation & $\begin{array}{c}\text { Without Suicidal } \\
\text { Ideation }\end{array}$ & \\
& Mean $(\mathbf{s d})$ & Mean(sd) & p value \\
\cline { 2 - 4 } GDS & $18.9(3.8)$ & $14.6(4.8)$ & 0.0001 \\
Total BHS & $12.2(4.6)$ & $8.6(5.6)$ & 0.0002 \\
Feelings and expectations for the future & $3.3(1.6)$ & $1.9(1.8)$ & 0.0001 \\
Loss of motivation & $4.4(1.8)$ & $3.36(2.1)$ & 0.004 \\
Hope & $4.4(1.8)$ & $3.28(2.2)$ & 0.002 \\
Total RLI & $243.7(32.2)$ & $267.2(24.3)$ & 0.0001 \\
General optimism & $94.0(17.7)$ & $111.3(15.6)$ & 0.0001 \\
Moral and religious obstacles & $43.5(4.8)$ & $43.3(5.1)$ & 0.77 \\
Responsibility and love for the family and friends & $48.9(6.2)$ & $51.2(4.4)$ & 0.01 \\
Fear of suicide and its negative consequences & $34.0(5.3)$ & $36,8(6.1)$ & 0.008 \\
Devotion to nature and life & $14.9(2.8)$ & $15.8(2.6)$ & 0.06 \\
Fear of death & $8.6(2.7)$ & $10.1(3.4)$ & 0.01 \\
\hline
\end{tabular}

suicidal ideation, whereas two did not and there was a significant relationship between the two groups. One study reported that unlike the high suicide rate among the elderly, suicidal ideation decreases with age but remains a risk factor for suicide attempts ${ }^{13}$. Rushing et al. concluded that suicidal ideation among the elderly was higher for patients who had made prior suicide attempts, thereby supporting the findings of this study ${ }^{14}$. Among studies expressing their views on different aspects of suicide, Miller et al. compared young and elderly adults and found no differences in suicidal ideation between the two groups ${ }^{15}$.

The prevalence of psychiatric disorders occurring along with suicide is very high ${ }^{16}$. When we compared patients with and without suicidal ideation (according to the distribution of psychi- atric disorders in this study), we found that patients with suicidal ideation were diagnosed, for the most part, as suffering from depressive disorder with generalized anxiety disorder as a comorbidity. Although this finding was not statistically significant, we believe that it would be significant with a greater number of patients. One study in UK that included participants aged 16-74 years found the depressive disorder rate in the elderly individuals with suicidal ideation to be significantly higher than the depressive disorder rate in younger individuals ${ }^{17}$. A stronger correlation was found between world weariness with thoughts of death and depression in the elderly. Almeida et al. examined 155 elderly individuals in Portugal and found high rates of depression in the elderly with suicidal ideation $^{18}$. 


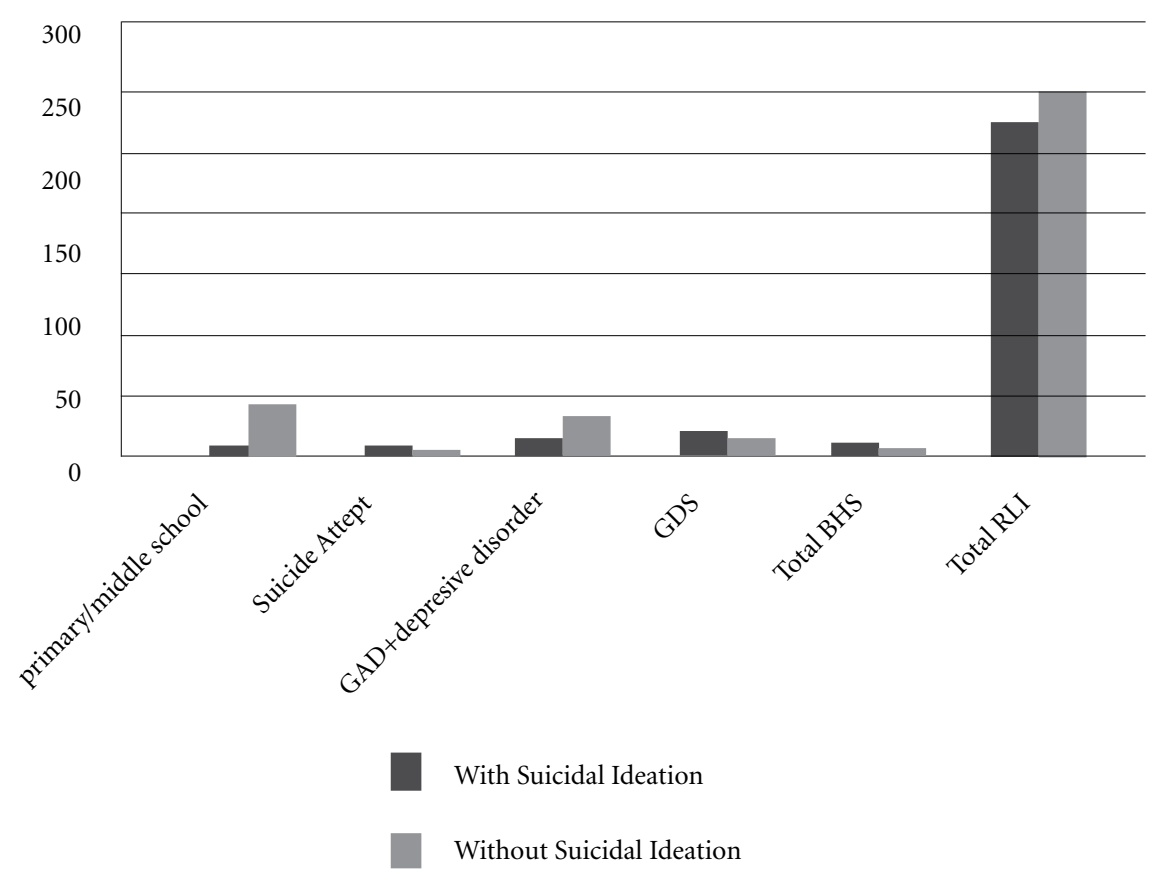

Graphic 1. Comparison of socio-demographic, clinical characteristics and mean (sd)scores from the Geriatric Depression Scale (GDS), the Beck Hopelessness Scale (BHS), and the Reasons for Living Inventory (RLI) of patients with and without suicidal ideation.

In the present study, we found that the mean GDS scores in the group with suicidal ideation were higher than those scores in the group without suicidal ideation, and this finding was statistically significant. Furthermore, we found a close relationship between higher mean SIS scores and depression level in the group with suicidal ideation. This finding is consistent with two findings in the literature that found the severity of depression in the elderly to be the strongest predictor of the course of suicidal ideation and the level of depression among patients, and this is consistent with the literature ${ }^{19}$.

When we analysed the BHS total and subscale scores in our study, we found the scores to be higher in the group with suicidal ideation than those in the group without suicidal ideation, and this finding was statistically significant. Uncapher et al. found that the relationship between hopelessness and depression in the elderly depends on the depression level ${ }^{20}$. It was reported that the elderly with moderate and high depressive symptom levels experienced an increase in suicidal ideation with an increase in despair. Although a number of findings have demonstrated a stronger relationship between depression and suicidal ideation with high despair levels, some studies consider that despair is a better predictor than depressive symptoms for suicidal ideation ${ }^{3,4}$. In another study consistent with our findings, Lau et al. who compared two groups of elderly patients with and without suicidal ideation found stronger feelings of hopelessness in the group with suicidal ideation ${ }^{21}$. Consistent with this finding, Hill et al. found that hopelessness is effective for predicting suicidal ideation in patients admitted to outpatient clinics ${ }^{22}$.

When we evaluated RLI scores, we found that in the group with suicidal ideation, the total mean scores for general optimism, responsibility and love towards friends and family, fear of committing suicide and its negative consequences and fear of death subscales were lower than those for moral and religious barriers and devotion to nature and life subscales, which was statistically significant. We noted a very slight increase in moral and religious beliefs being the reason for living in patients with suicidal ideation compared with those without suicidal ideation. However, a significant decrease in all survival causes 
was observed. This situation can be interpreted as one where moral and religious barriers result in a prohibitive and preventive effect in patients with suicidal ideation. In a study comparing young adults with the elderly, the presence of children and moral and religious barriers were identified as important preventive and protective factors with regard to suicide in the elderly as a result of implementation of RLI on participants ${ }^{15}$. It can be noted that the presence of suicidal ideation caused a more intense despair in the elderly. With respect to gender, the mean scores of women from all subscales were significantly higher than those of men. Two studies in our country reported that the total mean BHS scores of elderly women were higher than those of elderly men ${ }^{13,23}$.

According to an assessment made with participants living alone or with someone else, it was found that there was a significant difference between all BHS subscales and the relationship of groups with and without suicidal ideation. From three subscales, those living alone had higher mean scores than those living with someone else. In a field study by Stravynski and Boyer with approximately 20.000 individuals, it was found that loneliness increased both suicidal ideation and suicide attempts, thereby implying that elderly individuals living with their spouses, children or grandchildren have social support and are more hopeful regarding life ${ }^{24}$. However, suicide may be an expression of the fact that the elderly cannot endure loneliness.

In this study, a significant difference was observed in comparing the subscales between groups with and without chronic disease. In the groups with and without suicidal ideation, a higher mean score of hope subscales was observed in patients with chronic diseases than those without chronic diseases, and the difference was statistically significant. Yip et al. (2003) reported that, elderly individuals with a physical disease had more suicidal ideation than healthy individuals ${ }^{25}$. Most individuals in this study had a chronic disease; very few of them did not have a chronic disease. This may be the reason for a statistically significant result of being not determined.

With respect to the evaluation of the presence of chronic diseases, the mean scores obtained from RLI subscales of patients with suicidal ideation were lower than those without suicidal ideation. The scores were found to be statistically significant in terms of other scales except the moral and religious barrier subscale. However, a significant difference was found between groups with and without chronic diseases with respect to the moral and religious barrier subscale. It can be interpreted that moral and religious beliefs as survival causes become significantly less important if elderly individuals suffer from a chronic disease.

\section{Limitations}

The main limitation of this cross-sectional study is that the entire study population comprised patients selected from one centre in Turkey, thereby rendering it impossible to make meaningful generalizations of the findings. In addition, the results of study cannot be generalized to the elderly in other countries because the instruments used in the study are not not validated for other countries (eg Brazil). This situation is a limitation of study. We believe that a multicentre study with a larger sample would facilitate meaningful generalizations and add more statistical power.

\section{Conclusions}

In this study, we found low education status, lack of reasons for living (i.e. responsibility and love for the family and friends), previous suicide attempts, presence of generalized anxiety disorder and comorbid depressive disorder in with suicidal ideation among the elderly people. It is necessary to evaluate physical, economic, social, and psychological problems arising in the old age in detail. Practices to reduce of suicide include examining old patients' suicidal ideation as well as diagnosis and treatment of chronic physical illnesses or psychiatric disorders causing capacity deficiency. All healthcare personnel should be sensitive to elderly people's suicidal ideation in order to prevent suicides in elderly population.

\section{Collaborations}

All the authors contributed to the preparation of the manuscript. The article was designed by $\mathrm{M}$ Aslan, C Hocaoglu and B Bahceci. The analysis and interpretation of the data was done by $\mathrm{M}$ Aslan and $\mathrm{C}$ Hocaoglu. The review and approval of the final version was made by $\mathrm{C}$ Hocaoglu. 


\section{References}

1. Bhar SS, Wiltsey-Stirman S, Zembroski D, Zembroski D, McCray L, Oslin DW, Brown GK, Beck AT.Recruiting older men for geriatric suicide research. Int Psychogeriatr 2013; 25(1):88-95.

2. Ozguven HD. The epidemiology of suicidal behavior. Turkey Clinics Journal of Psychiatry-Special Topics 2008; 1(3):1-7.

3. Raue PJ, Ghesquiere AR, Bruce ML. Suicide risk in primary care: identification and management in older adults. Curr Psychiatry Rep 2014; 16(9):1-8.

4. Edelstein B, Kalish KD, Drozdick LW, McKee DR. Assesment of depression and bereavement in older adults. In: Lichtenberg PA, editor. Handbook of Assesment in Clinical Gerontology. New York: John Wiley \& Sons; 1999. p. 11-23.

5. Garand L, Mitchell AM, Dietrick A, Hijjawi SP, Pan D. Suicide in older adults: nursing assessment of suicide risk. Issues Ment Health Nurs 2006; 27(4):355-370.

6. Ertan T, Eker E, Sar V. Validity and reliability of the Turkish elderly population of the Geriatric Depression Scale. Arch Neuropsychiatry 1997; 33:62-71.

7. Dilbaz N, Holat H, Bayam G, Tüzer T. The reliability and validity of suicidal ideation scale. 31. Ulusal Psikiyatri Bilimler Kongresi Bilimsel Çalışma Kitabı 1995; 40-1. (Turkish)

8. Durak A, Palabiyikoğlu R. The Reliability and Validity of Beck Hopelessness Scale. Crisis 1994; 2:311-319.

9. Durak A, Yasak-Gültekin Y, Şahin NH. The reliability and validity of Reasons for Living Inventory. Turkish Journal of Psychology 1993; 8:7-19.

10. Waern M, Beskow J, Runeson B, Skoog I. Suicidal feelings in the last year of life in elderly people who commit suicide. Lancet 1999; 354(9182):917-918.

11. Park JY, Han JW, Jeong H, Jeong HG, Kim TH, Yoon IY, Kim KW. Suicidal behaviors in elderly Koreans: Onemonth-point prevalence and factors related to suicidality. J Affect Disord 2013; 150(1):77-83.

12. Bekaroğlu M, Bilici M, Hocaoğlu C, Gurpınar S, Uluut$\mathrm{ku}$ N. The incidence of suicide attempts in Trabzon in 1995. Turk Psikiyatri Derg 2000; 11(2):95-102.

13. Kızıl ETO, Yarpuz AY, Ekinci S, Sorgun M, Turan ED. An examination of suicidal behavior that refer to geropsychiatry clinic in depressed elderly. Turkish Journal of Geriatrics 2007; 10(2):57-60.

14. Rushing NC, Corsentino E, Hames JL, Sachs-Ericsson N, Steffens DC. The relationship of religious involvement indicators and social support to current and past suicidality among depressed older adults. Aging Ment Health 2013; 17(3):366-374.

15. Miller JS, Segal DL, Coolidge FL. A comparison of suicidal thinking and reasons for living among younger and older adults. Death Stud 2001; 25(4):357-365.
16. Minayo MC, Cavalcante FG, Mangas RM, Souza JR. Psychogical autopsies into suicide among the elderly in Rio de Janeiro. Cien Saude Colet 2012; 17(10):27732781.

17. Dennis M, Baillon S, Brugha T, Lindesay J, Stewart R, Meltzer H. The spectrum of suicidal ideation in Great Britain: Comparisons across a 16-74 years age range. Psychol Med 2007; 37(6):795-805.

18. Almeida L, Quintão S. Depression and suicidal ideation in elderly institutionalized and non-institutionalized in Portugal. Acta Med Port 2012; 25(6):350-358.

19. Bhar SS, Brown GK. Treatment of Depression and Suicide in Older Adults. Cogn Behav Pract 2012; 19(1):116-125.

20. Uncapher H, Gallagher-Thompson D, Osgood NJ, Osgood NJ, Bongar B. Hopelessness and suicidal ideation in older adults. Gerontologist 1998; 38(1):62-70.

21. Lau R, Morse CA, Macfarlane S. Psychological factors among elderly women with suicidal intentions or attempts to suicide: A controlled comparison. J Women Aging 2010; 22(1):3-14.

22. Hill RD, Gallagher D, Thompson LW, Ishida T. Hopelessness as a measure of suicide intent in the depressed elderly. Psychol Aging 1988; 3(3):230-232.

23. Gümüş AB, Ozgür G, Yıldırım S. Level of hopelessness among the elderly and affecting factors in living nursing homes. Journal of Ege University School of Nursing 2007; 23(2):105-116.

24. Stravynski A, Boyer R. Loneliness in relation to suicide ideation and parasuicide: a popülation-wide study. Suicide Life Threat Behav 2001; 31(1):32-40.

25. Yip PS, Chi I, Chiu H, Chi Wai K, Conwell Y, Caine E. A prevalence study of suicide ideation among older adults. Int J Geriatr Psychiatry 2003; 18(11):1056-1062.

Artigo apresentado em 08/02/2017

Aprovado em 09/08/2017

Versão final apresentada em 11/08/2017 